
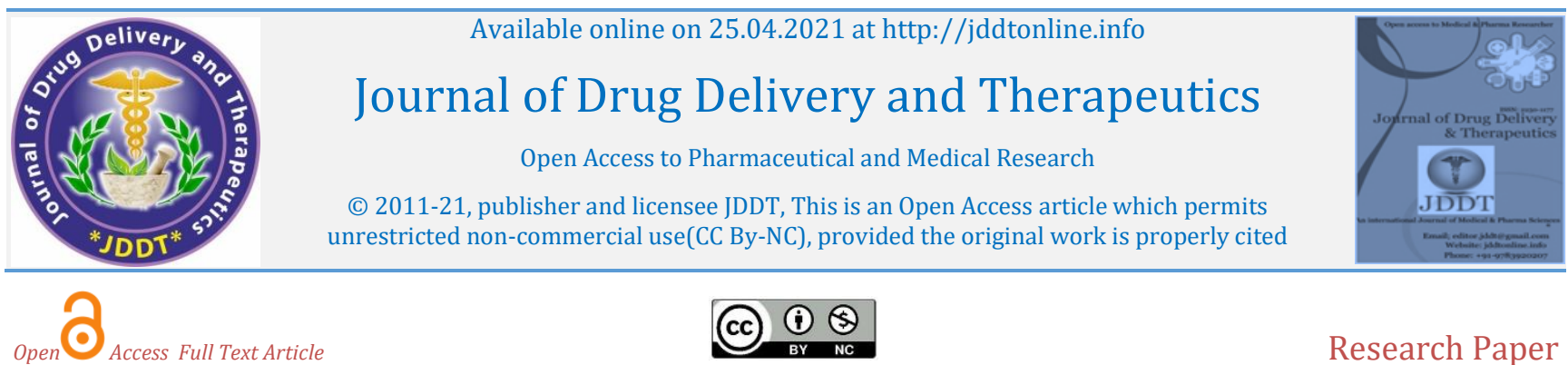

Research Paper

\title{
Synthesis, Characterization and Anti-Microbial Activity of Novel Pyramidine Derivatives
}

\author{
Konda Ravi Kumar*, K.N.S. Sneha Sumanjali, M. Priya Chandana, N. Srilatha, P. Koteswara Rao \\ Department of Pharmaceutical Chemistry, Hindu College of Pharmacy, Guntur, A.P-522002, India
}

\section{Article Info:}

\section{口回四 Article History:}

Received 18 Feb 2021 Review Completed 07 April 2021 Accepted 14 April 2021 Available online 25 April 2021

Cite this article as:

Ravi Kumar K, Sumanjali KNSS, Chandana MP, Srilatha N, Koteswara Rao P, Synthesis,

Characterization and Anti-Microbial Activity of Novel Pyramidine Derivatives, Journal of Drug Delivery and Therapeutics. 2021; 11(2-s):98-102

DOI: http://dx.doi.org/10.22270/jddt.v11i2-s.4694

*Address for Correspondence:

Dr. Konda Ravi Kumar, Professor, Hindu college of Pharmacy, Guntur, A.P-522002, India

\section{Abstract}

Pyrimidine is a heterocyclic aromatic organic compound similar to benzene and pyridine, containing two nitrogen atoms at positions 1 and 3 of the six-member ring. Three nucleobases found in nucleic acids, cytosine (C), thymine (T), and uracil (U), are pyrimidine derivatives. A pyrimidine has many properties in common with pyridine, as the number of nitrogen atoms in the ring increases the ring pi electrons become less energetic and electrophilic aromatic substitution gets more difficult while nucleophilic aromatic substitution gets easier. Chalcones react with aminoguanidine to give intermediate compounds which on further reacts with substituted ketones to give Pyramidine derivatives. A total of 6 compounds were synthesized from one scheme and they were recrystallized by appropriate solvents. They were identified and characterized by various spectral methods. In the present study, all synthesized compounds tested for anti bacterial activity and anti-fungal activity. They shown significant activity when compared with standard drug Streptomycin and Miconazole respectively.

Keywords: Pyramidines, Characterization, Streptomycin, Miconazole, Anti-microbial activity.

\section{INTRODUCTION}

Pyrimidine is a heterocyclic aromatic organic compound similar to benzene and pyridine, containing two nitrogen atoms at positions 1 and 3 of the six-member ring. ${ }^{1}$ Three nucleobases found in nucleic acids, cytosine (C), thymine (T), and uracil (U), are pyrimidine derivatives. A pyrimidine has many properties in common with pyridine, ${ }^{2}$ as the number of nitrogen atoms in the ring increases the ring pi electrons become less energetic and electrophilic aromatic substitution gets more difficult while nucleophilic aromatic substitution gets easier ${ }^{3-4}$. Reduction in resonance stabilization of pyrimidines may lead to addition and ring cleavage reactions rather than substitutions. ${ }^{5-6}$ Pyrimidine derivatives possess very interesting pharmacological and biological properties and are reported to exhibit variety of biological activities like antibacterial, antifungal and anticonvulsant, analgesic, anti-inflammatory, antihelmentic, sedative, hypnotic, antispasmodic,7-10 local anaesthetic Antitubercular, antihistaminic, antioxidant and anticancer activity. ${ }^{11-14}$

\section{MATERIALS AND METHODS}

Melting points of the synthesized compounds were determined in open capillary tubes and were uncorrected.IR spectra were recorded on BRUKER FT-IR spectrometer using ATR. ${ }^{1} \mathrm{HNMR}$ spectra of the compounds in deuteriated dimethyl sulfoxide and $\mathrm{CDCl}_{3}$ was recorded on Bruker Av 400 spectrometer. Mass spectra were recorded on LCMS QP 5000 Schimadzu.Thin layer Chromatography was performed using pre-coated aluminium plates, coated with silica gel $\mathrm{GF}_{254}$ [E.Merck].Ethyl acetate:Methanol in the ratio of 3:2 was used as the eluent. The spots were visualized in the UV/Iodine chamber. 


\section{EXPERIMENTAL WORK}

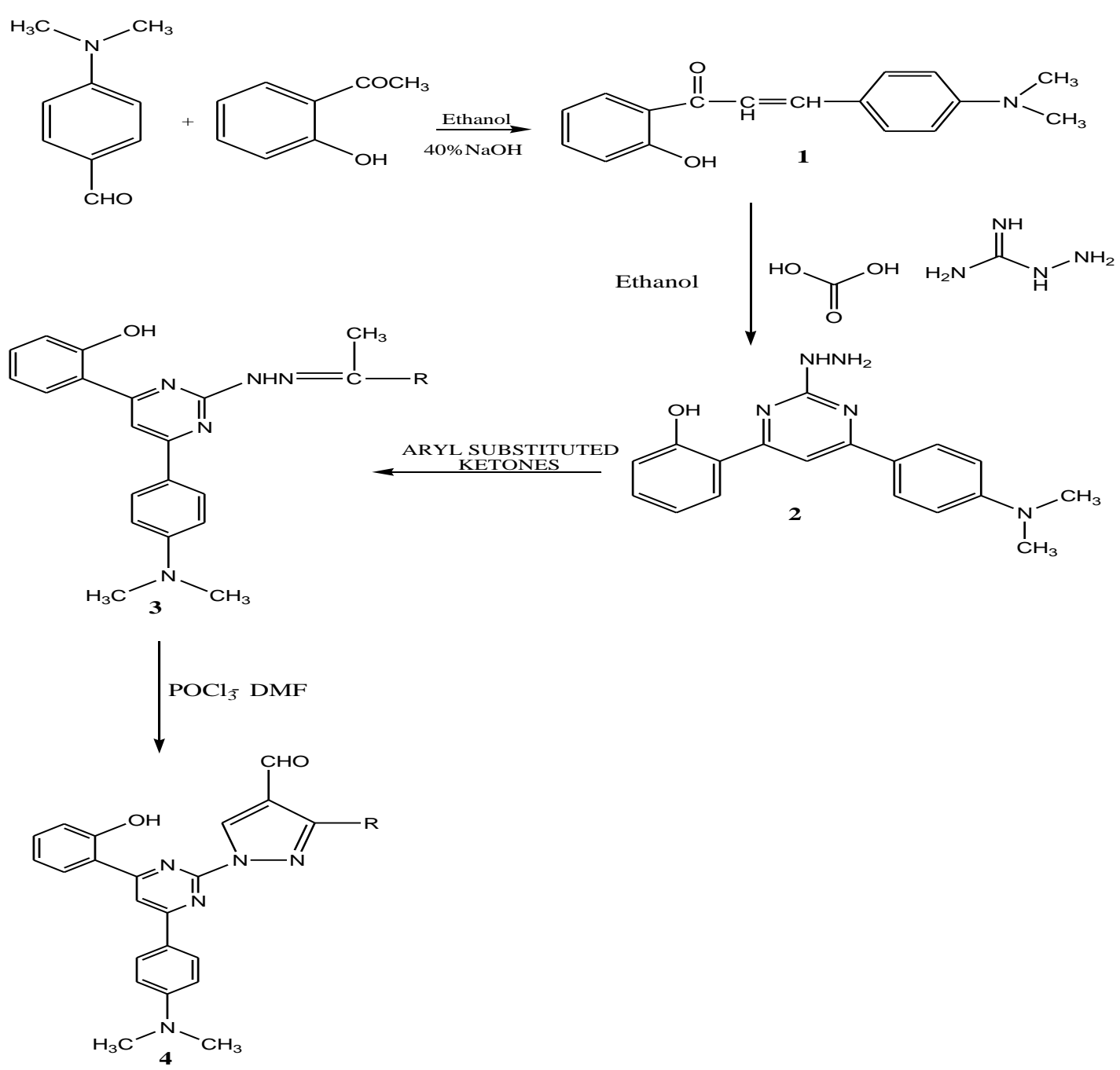

SCHEME - 1

\section{STEP-1: Synthesis of 5-amino tetrazole (1)}

\section{Thiele method}

$34 \mathrm{~g}(0.25 \mathrm{~mol})$ of amino guanidine bicarbonate is added to $217 \mathrm{ml}$ of $15 \%$ nitric acid $(0.561 \mathrm{~mol})$, and mixed until evaluation of carbon dioxide is stopped and resulted amino guanidine nitrate is fully dissolved in solution. Yellow transparent solution is diazotised by slow addition of $17.2 \mathrm{~g}$ sodium nitrite $(0.25 \mathrm{~mol})$ in $35 \mathrm{ml}$ of water. Addition is accompanied by stirring, and temperature during all addition period is kept between $20-25^{\circ} \mathrm{C}$ by using water bath if needed. After completion of reaction the diazotisation mixture is allowed to sit for $20 \mathrm{~min}$ at room temperature. And $29 \mathrm{~g}$ of sodium carbonate is added (or $46 \mathrm{~g}$ of sodium bicarbonate). Mixture is then heated on a water bath and refluxed for $4 \mathrm{hrs}$. The solution is then neutralized by $30 \%$ sulphuric acid to $\mathrm{ph}=4$, cooled to room temperature and allowed to sit over night. The precipitated crystals of 5- amino tetrazole monohydrate are filtered, washed with cold water and dried. Yield is about $70-74 \%$ based on amino guanidine.

STEP-2: Synthesis of N-Substituted benzylidene-1Htetrazol-5-amine (2)

To the mixture of $(0.01 \mathrm{~mol})$ of compound was added $(0.01 \mathrm{~mol})$ substituted benzaldehydes and $20 \mathrm{ml}$ of ethanol taken in RBF and was refluxed on a water bath for $2 \mathrm{hrs}$. The resultant solution was cooled; the solid that separated was filtered and recrystallized from pet ether.

STEP-3: Synthesis of 2,3-dihydro-2-substituted phenyl-3(1H tetrazoll-5-yl)thiazol-4-one (3)

To mixture of compound, $8 \mathrm{ml}$ of ethanol $(0.2 \mathrm{~mol}), 0.1 \mathrm{~g}$ of zinc chloride and $0.4 \mathrm{ml}(0.004 \mathrm{~mol})$ of thioglycolic acid was added and the mixture was refluxed for 8hrs. After that the solid was separated out. 


\begin{tabular}{|c|c|c|}
\hline S.NO & CODE & \\
\hline 1. & PYR-1 & \\
\hline 2. & PYR-2 & \\
\hline 3. & PYR-3 \\
\hline
\end{tabular}<smiles></smiles>

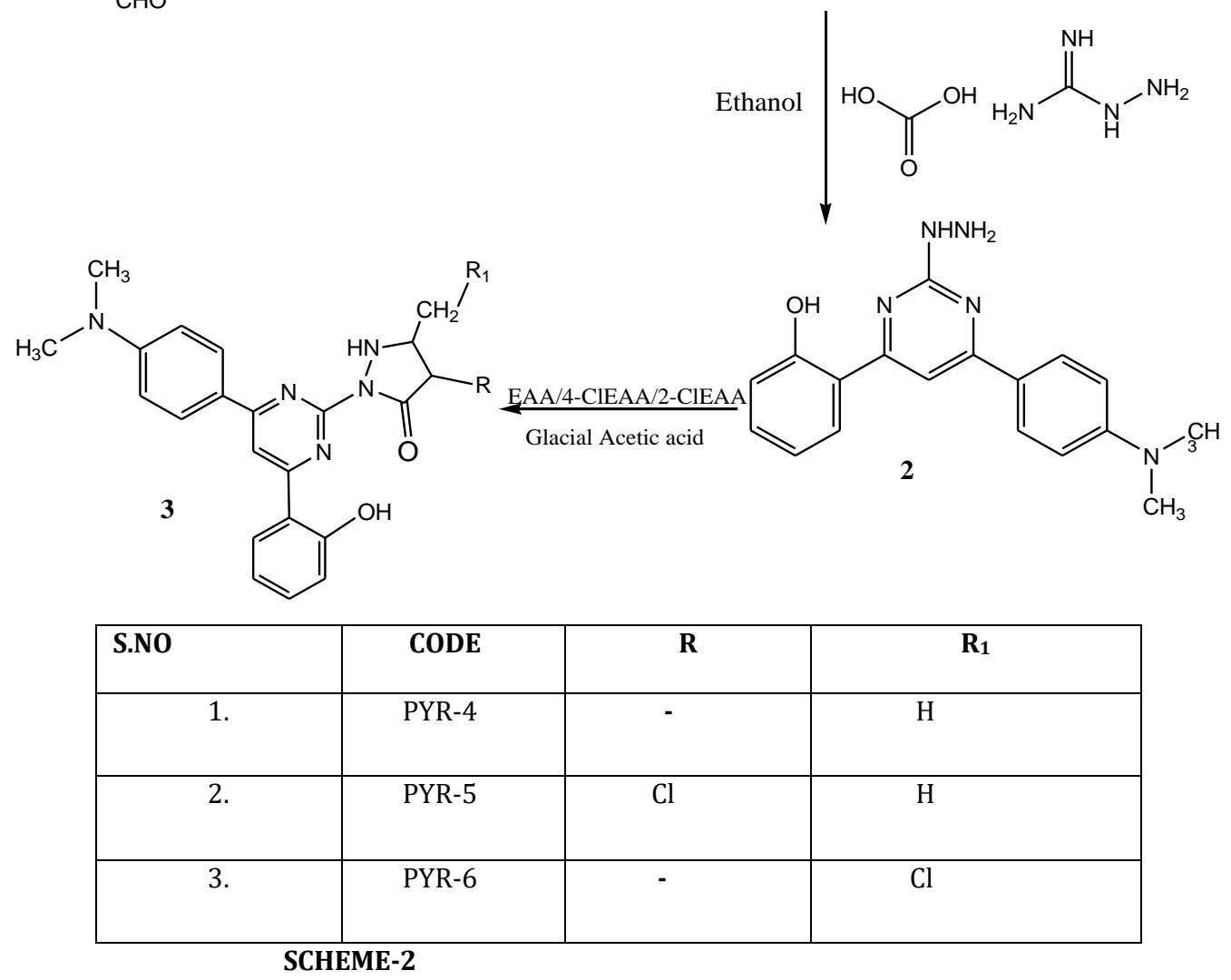




\section{RESULTS AND DISCUSSION}

A total of $\mathbf{6}$ compounds were synthesized from two schemes and they were recrystallized by appropriate solvents. They were identified and characterized by various spectral methods. All the compounds were tabulated and characterization data was tabulated in Tab.1.

IR (KBr): $\mathbf{C m}^{-1}: 3057.19$ (C-H;Str.), 1666.16(C=N;Str.), 1576.82,1500.21(C=C,Str.), 749.77(C-H; Bend), 1180.50(CN;Str.),1328.21(C-O;Str.), 1129.21(O-H; Bend), 2885.72(methyl;Str.)

IR (KBr): Cm-1: 2999.77(C-H;Str.),

1570.00,15518.96,1481.89(C=C;Str.),757.10 (C-H; Bend),

1164.53(C-N; Bend), 1236.58(O-H; Bend), 1408.59(C-O;

Str.), 2887.59 (C-H;Str.), 1307.91(C-H; Bend), 757.10(C-Br; Str.).

IR (KBr): Cm$^{-1}: 2982.63(\mathrm{C}-\mathrm{H} ; \mathrm{Str}$ ),

1569.41,1515.91,1478.60(C=C;Str), 739.33 (C-H;Bend),
1230.74(O-H;Bend),1413.02(C-0;Str),2891.11(C-

$\mathrm{H} ; \mathrm{Str}), 1341.39$ (C-H;Bend)

IR (KBr): Cm$^{-1}:$ 1686.84(C=N;Str.), 2919.78(C-H;Str.), 1341.57(C-H;Bend),

1610.5,1567.05,1515.91,1475.59(C=C;Str.), 743.39(C-H; Bend), 1153.68(C-N;Str.), 1367.57(C-O; Str.), 1194.92(OH; Bend)

IR (KBr): $\mathbf{C m}^{-1}:$ 1671.85(C=N;Str.), 2791.88(C-H;Str.), 1341.14(C-H; Bend),

1610.11,1566.69,1515.45,1479.36(C=C; Str.), 744.52(C-H; Bend), 1151.43(C-N; Str.), 1366.16(C-O; Str.), 1193.13(OH; Bend), 809.58(C-Cl, Str.)

IR (KBr): Cm$^{-1}:$ 1671.85(C=N;Str.), 2791.88(C-H;Str.), 1341.14(C-H; Bend),

1610.11,1566.69,1515.45,1479.36(C=C; Str.), 744.52(C-H; Bend), 1151.43(C-N; Str.), 1366.16(C-O; Str.), 1193.13(OH; Bend), 809.58(C-Cl, Str.)

Table 1: Characterization data of Synthesized compounds.

\begin{tabular}{|l|l|c|c|c|}
\hline $\begin{array}{c}\text { Compound } \\
\text { Code }\end{array}$ & \multicolumn{1}{|c|}{ Mole. Formula } & $\begin{array}{c}\text { Mole. } \\
\text { Weight. } \\
\text { (g/mole) }\end{array}$ & $\begin{array}{c}\text { Melting } \\
\text { Point } \\
\text { ('0) }\end{array}$ & \% Yield \\
\hline PYR-1 & $\mathrm{C}_{29} \mathrm{H}_{23} \mathrm{~N}_{5} \mathrm{O}_{4}$ & 505.52 & $230-238$ & 54.24 \\
\hline PYR-2 & $\mathrm{C}_{29} \mathrm{H}_{23} \mathrm{BrN}_{4} \mathrm{O}_{2}$ & 539.42 & $194-198$ & 60.36 \\
\hline PYR-3 & $\mathrm{C}_{29} \mathrm{H}_{25} \mathrm{~N}_{5} \mathrm{O}_{2}$ & 475.54 & $210-216$ & 58 \\
\hline PYR-4 & $\mathrm{C}_{22} \mathrm{H}_{23} \mathrm{~N}_{5} \mathrm{O}_{2}$ & 389.45 & $154-158$ & 62.12 \\
\hline PYR-5 & $\mathrm{C}_{22} \mathrm{H}_{22} \mathrm{Cl} \mathrm{N}_{5} \mathrm{O}_{2}$ & 423.9 & $144-150$ & 53.12 \\
\hline PYR-6 & $\mathrm{C}_{22} \mathrm{H}_{22} \mathrm{Cl} \mathrm{N}_{5} \mathrm{O}_{2}$ & 423.9 & $200-208$ & 49.59 \\
\hline
\end{tabular}

\section{Anti-bacterial activity of synthesized compounds}

A total of $\mathbf{6}$ compounds were synthesized from one scheme and they were recrystallized by appropriate solvents. They were identified and characterized by various spectral methods. Synthesized Pyrimidine derivatives were evaluated for Anti-bacterial activity with cup plate method at concentrations of $50 \mu \mathrm{g} / \mathrm{ml}$ and $100 \mu \mathrm{g} / \mathrm{ml}$.Standard was taken as streptomycin Control was taken as ethanol. The results were tabulated in Tab.2. PYR-3 is effective against both Gram +ve and Gram -ve, PYR-1 and PYR-2 are found to have moderate activity against both Gram +ve and Gram -ve where as PYR-1 showed activity against E.coli. Other compounds having insignificant activity when compared to standard Streptomycin.

Table 2: Anti-bacterial activity of synthesized compounds.

\begin{tabular}{|c|c|c|c|c|c|c|c|}
\hline \multirow[t]{3}{*}{ S. No } & \multirow[t]{3}{*}{ Compound Code } & \multicolumn{4}{|c|}{ Gm +Ve } & \multirow{2}{*}{\multicolumn{2}{|c|}{$\begin{array}{l}\text { Gm -Ve } \\
\text { E.Coli }\end{array}$}} \\
\hline & & \multicolumn{2}{|c|}{ S.aureus } & \multicolumn{2}{|c|}{ B. Pimilis } & & \\
\hline & & $\begin{array}{c}50 \\
\mu \mathrm{g} / \mathrm{ml}\end{array}$ & $\begin{array}{c}100 \\
\mu \mathrm{g} / \mathrm{ml}\end{array}$ & $\begin{array}{c}50 \\
\mu \mathrm{g} / \mathrm{ml}\end{array}$ & $\begin{array}{c}100 \\
\mu \mathrm{g} / \mathrm{ml}\end{array}$ & $\begin{array}{c}50 \\
\mu \mathrm{g} / \mathrm{ml}\end{array}$ & $\begin{array}{c}100 \\
\mu \mathrm{g} / \mathrm{ml}\end{array}$ \\
\hline 1. & PYR-1 & - & 11 & - & - & 13 & 16 \\
\hline 2. & PYR-2 & 10 & 12 & - & - & - & - \\
\hline 3. & PYR-3 & 10 & 11 & 14 & 10 & 12 & 15 \\
\hline 4. & PYR-4 & - & 12 & - & - & - & - \\
\hline 5. & PYR-5 & - & - & 10 & 11 & - & - \\
\hline 6. & PYR-6 & - & 14 & - & - & 15 & - \\
\hline Control & Ethanol & & & & & & \\
\hline Standard & $\begin{array}{l}\text { Streptomycin } \\
(100 \mu \mathrm{g} / \mathrm{ml})\end{array}$ & & & & & & \\
\hline
\end{tabular}




\section{Anti-fungal activity of synthesized compounds}

PYR-1 and PYR- 6 are effective against both organisms was found to have moderate activity and PYR-3\& 5 showed activity against pencillium notatum. Other compound every having insignificant activity when compared to standard Miconazole.

Table 3: Anti-fungal activity of the synthesized compounds.

\begin{tabular}{|c|c|c|c|c|c|}
\hline \multirow[t]{2}{*}{ S.NO } & \multirow[t]{2}{*}{ Compound code } & \multicolumn{2}{|c|}{ Aspergillus niger } & \multicolumn{2}{|c|}{ Penicillum notatum } \\
\hline & & $50 \mu \mathrm{g} / \mathrm{ml}$ & $100 \mu \mathrm{g} / \mathrm{ml}$ & $50 \mu \mathrm{g} / \mathrm{ml}$ & $100 \mu \mathrm{g} / \mathrm{ml}$ \\
\hline 1. & PYR-1 & 8 & 10 & 13 & 17 \\
\hline 2. & PYR-2 & - & - & 9 & 11 \\
\hline 3. & PYR-3 & - & - & 8 & 13 \\
\hline 4. & PYR-4 & - & 10 & - & 11 \\
\hline 5. & PYR-5 & - & - & 9 & 11 \\
\hline 6. & PYR-6 & 12 & 14 & 8 & 10 \\
\hline Control & Ethanol & & & & \\
\hline Standard & Miconazole $(50 \mu \mathrm{g} / \mathrm{ml})$ & & & & \\
\hline
\end{tabular}

\section{CONCLUSION}

We have described simple and efficient protocol for the synthesis of novel pyramidine derivatives with good yields. The schemes include Chalcones react with aminoguanidine to give intermediate compounds which on further reacts with substituted ketones to give 6 Pyramidine derivatives. A total of 6 compounds were synthesized from one scheme and they were recrystallized by appropriate solvents. They were identified and characterized by various spectral methods. In the present study, all synthesized compounds tested for anti bacterial activity and anti-fungal activity. They shown significant activity when compared with standard drug Streptomycin and Miconazole respectively. Among the synthesized compounds some of the compounds possess moderate to promising activity when compared with standard. All the compounds show dose dependent activity.

\section{REFERENCES}

1. Chaithanya MS, Vaidya VP, Nagendrappa G; "Synthesis and biological activity of 2-amino-4H-pyrimido $[2,1$ b][1,3]benzothiazoles-3-carboxylates", Asian journal of chemistry, apr 2011; 23(4):1618-1620.

2. Rajendra Prasad Y, Bhaskar Rao B, Agarwal NK, Srinivasa Rao A, "Synthesis and Antimicrobial activity of some new 2, 4, 6trisubstituted pyrimidines", Asian journal of chemistry , feb 2011; 23(2):641-644.

3. Babu AN, Nadendla RR; "Synthesis and Antimicrobial activity of 1-substituted phenyl -3-substituted phenyl-4-[3, 4, 5trimethoxy)-5-benzyl]-4-aminopyrimidine formazans" Asian journal of chemistry, jan 2011; 23(1):278-280.

4. Thore SN; "Synthesis of some 3, 5-bis-1, 4-dihydro-4-phenyl 2, 6-dimethyl pyridine-21-amino-61-phenyl pyrimidines", Asian journal of chemistry, jan 2007; 19(6):4429-4432.
5. Mobinikhaledi A, Forughifar N, Shariatzadeh SM, Ghaznavi E; "Synthesis and biological activities of some oxazolo and oxothiazolo pyrimidines", Asian journal of chemistry, 2007; 19(1):228-232.

6. Kumar N, Tiwari S, Yadav AK; "Pyrido [2, 3-d] pyrimidines and their ribofuranosides: Synthesis and antimicrobial investigations", Indian journal of chemistry, april 2007; 46:702706.

7. Akbari JD, Mehta KB, Pathak SJ, Joshi HS; "synthesis and antimicrobial activity of some new pyrazolo [3, 4-d] pyrimidines and thiazolo [4, 5-d] pyrimidines", Indian journal of chemistry, March 2008; 47B:477-480.

8. Vijaya Kumar P, Manohar Reddy K, Rajeswar Rao V; "Synthesis of some 7-methyl-3-(2-oxo-2H-chromen-3-yl)-5H [1,3] thiazolo[3,2-a-]-pyrimidine-5-ones", Indian journal of chemistry, May 2008; 47B:759-763.

9. Sondhi SM, Dinodia M, Rani R, Shukla R, Raghubir R; "Synthesis, anti-inflammatory and analgesic activity evaluation of some pyrimidine derivatives", Indian journal of chemistry, feb 2009; 49B:273-281.

10. Rashinkar GS, Pore SB, Mote KB, Salunkhe RS; "An efficient synthesis of novel 2-amino-4-aryl-6-ferrocenyl pyrimidines", Indian journal of chemistry, April 2009; 48B:606-610.

11. Rana PB, Patel JA, Mistry BD, Desai KR; “Microwave and conventional techniques for the synthesis of a series of pyrazolo[5,4-d]-pyrimidine derivatives and their antimicrobial screening", Indian journal of chemistry, NOV 2009; 48B:16011608.

12. Lanjewar KR, Rahatgaonkar AM, Chorghade MS, Saraf BD; "Synthesis and antimicrobial activity of 5-(2-aminothiazol-4-yl)3,4-dihydro-4-phenyl pyrimidin-2(1H)-one", Indian journal of chemistry, DEC 2009; 48B:1732-1737.

13. Chattopadhyay G, Saha D, Ray PS, Naskar S, Sarkar S; "Synthesis of novel thiazolo[5,4-d]pyrimidines" Indian journal of chemistry, Sep 2010; 49B:1229-1234.

14. Rajanarendar E, Raju S, Nagi Reddy M, Rama Murthy K, "An elegant one-pot synthesis of isoxazolo [2, 3-a] pyrimidines", Indian journal of chemistry, oct 2010; 49B:1422-1427. 